\title{
Clinical application of mesenchymal stem cells for cartilage regeneration
}

\author{
Yu-Chun Chen ${ }^{1,2}$, Chih-Hung Chang ${ }^{1,3}$ \\ 'Department of Orthopedic Surgery, Far Eastern Memorial Hospital, New Taipei 220, Taiwan. \\ ${ }^{2}$ College of General Studies, Yuan Ze University, Taoyuan 320, Taiwan. \\ ${ }^{3}$ Graduate School of Biotechnology and Bioengineering, Yuan Ze University, Taoyuan 320, Taiwan.
}

Correspondence to: Prof. Chih-Hung Chang, Department of Orthopedic Surgery, Far Eastern Memorial Hospital, No. 21, Sec. 2, Nanya S. Rd., Banqiao Dist., New Taipei 220, Taiwan. E-mail: orthocch@mail.femh.org.tw

How to cite this article: Chen YC, Chang $\mathrm{CH}$. Clinical application of mesenchymal stem cells for cartilage regeneration. Plast Aesthet Res 2020;7:49. http://dx.doi.org/10.20517/2347-9264.2020.28

Received: 27 Feb 2020 First Decision: 12 May 2020 Revised: 13 Jun 2020 Accepted: 17 Jul 2020 Published: 17 Sep 2020

Academic Editor: Yi-Lin Cao Copy Editor: Cai-Hong Wang Production Editor: Jing Yu

\begin{abstract}
Cartilage has the ability to transmit and distribute loads, providing lubrication in the diarthrodial joints. Risk factors including age, gender, genetics, nutrition and bone density may predispose to osteoarthritis (OA) and cartilage defect formation. Appropriate treatment include sufficient rest and medical therapy. Intra-articular injections such as steroids, platelet-rich plasma, visco-supplementation and mesenchymal stem cells (MSCs) injections present as alternative options for non-operative treatments. For cartilage defects, microfracture (MF), osteochondral autograft transplantation (OAT) and autologous chondrocyte implantation $(\mathrm{ACl})$ are the most common treatment procedures. MSCs have been identified as an ideal cell source for OA therapy because they are easily expanded in culture, generally non-tumorigenic, and can be readily obtained from patients. It may be harvested from bone marrow (BMSCs), adipose tissue (ADSCs), synovium (SDSCs) or peripheral blood. BMSCs features the most common source of stem cells, and infrapatellar fat pad (IPFP) is another popular stem cell source. A phase 1 clinical study entitled "Treatment of Knee OA with Autologous Mesenchymal Stromal Cell Product (RegStem $\left.{ }^{\circledR}\right)$ " was conducted in Taiwan and utilized $5 \times 107$ IPFP-MSCs in the study for OA therapy. Most of the existing clinical studies have shown that patients receiving MSCs treatment have improved clinical outcome, such as Visual Analogue Scale, International Knee Documentation Committee and Western Ontario and McMaster Universities Arthritis Index (WOMAC) score. Some studies have also found an improvement in cartilage volume by Magnetic Resonance Imaging evaluation. Furthermore, MSCs can also be used for cartilage defect treatment. Clinical outcomes such as IKDC, Lysholm, and Tegner scores showed significant improvement when the cartilage defects were repaired and regenerated by several millions of stem cells. A 10-year follow-up clinical research indicated that there was no apparent increased tumor formation risk when BMSCs were used for cartilage defect treatment.
\end{abstract}

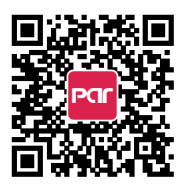


In addition, a BMSCs/collagen gel composite for cartilage repair clinical trial in Taiwan was conducted in 2008, and results suggested that there was an improvement in IKDC and MRI score at 9-years of follow-up. It appears that the use of MSCs for OA and cartilage defect treatment may be a promising method.

Keywords: Mesenchymal stem cell, osteoarthritis, cartilage defect, cartilage regeneration

\section{INTRODUCTION}

Cartilage offers high compressive force and covers the surfaces of synovial joints ${ }^{[1]}$. Its main function is to transmit and distribute loads and to further provide lubrication in the diarthrodial joints ${ }^{[2]}$. Healthy articular surfaces in humans demonstrate a hyaline cartilage morphology with thickness of about 2 to $4 \mathrm{~mm}$. Cartilage comprise of $65 \%-85 \%$ of water, $12 \%-24 \%$ of collagen, $3 \%-6 \%$ of glycosaminoglycans, and $16,000-$ 90,000 chondrocytes per microgram of wet tissue ${ }^{[3]}$. The biomechanical properties of articular cartilage are related to the composition and integrity of its extracellular matrix $(\mathrm{ECM})^{[4]}$. Cartilage may function well throughout life, but damage to this tissue is prominent and has been described to afflict more than 21 million patients each year in the United States alone.

Osteoarthritis $(\mathrm{OA})$ is one of the most common joint disorders related to cartilage ${ }^{[5]}$. In the United States alone, several millions of patients suffer from OA and treatment of this condition costs about 185.5 billion dollars annually ${ }^{[6]}$. OA pathology also ranks as the fourth leading cause of disability in Asia ${ }^{[7]}$ In addition, OA has a $12 \%$ prevalence rate in patients more than 60 years of age, and this is forecasted to increase within the next 10 years $^{[8]}$. It has also been reported that the incidence of OA has doubled in women, and tripled in men, in recent years ${ }^{[9]}$. Risk factors increasing its preponderance include that of age, gender, genetics, nutrition and bone density which lead to greater susceptibility in $\mathrm{OA}^{[5]}$.

Pro-inflammatory cytokines are also the critical mediators implicated in the pathophysiology of OA, where they affect both quantity and quality of the cartilage ECM. Interleukin 1 beta (IL-1 $\beta$ ), Tumor necrosis factor alpha (TNF- $\alpha$ ) and interleukin 6 (IL-6) are the main pro-inflammatory cytokines related to its pathogenesis. Elevated levels of IL-1 $\beta$ and TNF- $\alpha$ have been found in OA patient's synovial fluid, synovial membrane and subchondral bone. Several studies have also indicated that the presence of IL- $1 \beta$ and TNF- $\alpha$ down-regulated type II collagen and aggrecan expression in chondrocyte, subsequently stimulating the release of matrix metalloproteinase-1 (MMP-1), matrix metalloproteinase-3 (MMP-3) and matrix metalloproteinase-13 (MMP-13) ${ }^{[10,11]}$. IL-6 was also found to be elevated in OA patient's synovial fluid and sera ${ }^{[12]}$, and it up-regulated the expression of MMP- 1 and MMP- 13 in combination with IL- $1 \beta$ and oncostatin. These cytokines contribute to the pathogenesis of OA through down-regulation of anabolic events and up-regulation of catabolic and inflammatory responses, resulting in structural damage to the OA joint ${ }^{[13,14]}$.

Apart from OA, cartilage defects are another common source of joint disorders. Trauma, sports injuries, biomechanical imbalance and genetic disease are common causes of cartilage defect. Patients suffering from cartilage defects may experience pain and loss of articular function, with altered activities of daily living. According to the international cartilage repair society ICRS grading system ${ }^{[15]}$, cartilage defects can be ranked from grade 1 (mildest) to grade 4 (most severe) which implies the most serious cartilage defect. In grade 1, the cartilage lesions may be found within the superficial layers of the cartilage. Grade 2 lesions occur when its depth extends down to less than $50 \%$ of the cartilage depth. When the lesion extends down to more than $50 \%$ of the cartilage depth, this results in severely abnormal cartilage is classified as grade 3 . In the most severe defect grade 4, the lesion extends to subchondral bone and the underlying bony structures are exposed. When the defect areas are large, pain evolves to become more severe, and limits patients' daily activities. Hence, treatment of $\mathrm{OA}$ and cartilage defects is critical to improve the quality of life. 
Table 1. Different clinical strategies for osteoarthritis treatment

\begin{tabular}{|c|c|c|c|c|c|}
\hline $\begin{array}{l}\text { Treatment } \\
\text { strategies }\end{array}$ & Steroid injections $^{[77]}$ & $\begin{array}{c}\text { Visco-supplementation } \\
\text { injections }^{[78]}\end{array}$ & Prolotherapy & $\begin{array}{c}\text { Platelet-rich plasma } \\
\text { injections }\end{array}$ & MSCs injections $^{[20]}$ \\
\hline Functions & Symptom relief & Symptom relief & $\begin{array}{l}\text { Symptom relief and } \\
\text { tissue repair }\end{array}$ & $\begin{array}{l}\text { Symptom relief and } \\
\text { tissue repair }\end{array}$ & $\begin{array}{l}\text { Symptom relief and } \\
\text { tissue repair }\end{array}$ \\
\hline
\end{tabular}

MSCs: mesenchymal stem cells

\section{CLINICAL TREATMENT FOR OA AND CARTILAGE DEFECT}

\section{OA treatment}

Rest and medical therapy are the most common modalities of conservative treatment for OA, where the aim is to reduce the pain and not to repair the injury ${ }^{[16]}$. It is commonly advocated for patients with low grade OA. Intra-articular injections such as steroids, platelet-rich plasma and visco-supplementation have been used as alternative approaches to non-operative treatments ${ }^{[17]}$. However, there have been no evidence of structural improvement with the use of these conservative modalities to date. Several biologic adjuncts have been described to improve repair, including growth factors such as prolotherapy ${ }^{[18]}$, platelet rich plasma (PRP) ${ }^{[19]}$ and mesenchymal stem cells (MSCs) injection ${ }^{[20]}[$ Table 1].

\section{Cartilage defect treatment}

Clinical treatment of cartilage injury is dependent on age, modality of sport activities, etiology, grade and quality of the lesion. Rest and medical therapy remain the most common conservative treatment, but its objective is to reduce the pain, not to regenerate the cartilage. For patients with severe cartilage injury, operative treatments are necessary. Operative treatment for cartilage injuries depends on the patient's age, size of the lesion, and the chronicity of the lesion. Fresh osteochondral allograft is not available in many countries, hence microfracture (MF), osteochondral autograft transplantation (OAT) and autologous chondrocyte implantation (ACI) remain the most common procedures for cartilage restoration. MF is a surgery which creates small holes within the subchondral bone to allow blood and marrow healing elements into the area of damaged cartilage ${ }^{[21]}$. The MF defect is occasionally covered with a scaffold known as matrix augmented micro fracture, or autologous matrix-induced chondrogenesis. OAT is a technique to transfer healthy osteochondral tissue from a non-weight bearing site to the defect site ${ }^{[22]}$. Certain biphasic scaffolds have also been developed for osteochondral regeneration. ACI is a technique which involves performing an arthroscopy, obtaining a small piece of cartilage from the injured knee, expanding the chondrocytes in a GTP lab, and subsequently implanting the cells into the defect site ${ }^{[23]}$. Another improved ACI known as matrix-induced autologous chondrocyte implantation (MACI) is a technique which obtains patients' cartilage from a non-weight bearing area for cell culture, expanding the chondrocytes in a GTP lab, thereafter seeded them onto a specific scaffold for damaged area repair ${ }^{[24]}$ [Table 2].

Although commonly used, these treatments may have complications such as fibrocartilage formation in MF treatments, donor-site morbidity in OAT technique, and secondary surgery may be required in ACI and MACI procedures. Therefore, a simple and effective treatment based on the concept of tissue engineering for cartilage injury is needed.

\section{MSCS FOR OA AND CARTILAGE DEFECT TREATMENT MSCs}

MSCs present as an ideal cell source for OA therapy because they are easily expanded in culture, generally non-tumorigenic, and can be readily obtain from patients. More importantly, they possess immunosuppressive properties after exposure to an inflammatory environment with the secretion of soluble factors ${ }^{[25]}$. MSCs may be harvested from several sites including bone marrow (BMSCs), adipose tissue (ADSCs), synovium (SDSCs) or peripheral blood. Clinical applications of MSCs should meet the minimal 
Table 2. Different clinical strategies for cartilage defect treatment

\begin{tabular}{|c|c|c|c|c|c|c|}
\hline $\begin{array}{l}\text { Treatment } \\
\text { strategies }\end{array}$ & $\mathbf{M F}^{[21]}$ & AMIC & $\mathbf{O A T} \mathbf{T}^{[22]}$ & $\begin{array}{c}\text { Osteochondral } \\
\text { composites scaffold } \\
\text { implantation }\end{array}$ & $\mathrm{ACl}^{[23]}$ & $\mathrm{MACl}^{[24]}$ \\
\hline Procedures & $\begin{array}{l}\text { Using a small } \\
\text { bone pick to } \\
\text { punch into the } \\
\text { subchondral } \\
\text { bone causing } \\
\text { microfractures }\end{array}$ & $\begin{array}{l}\text { After } \\
\text { microfracture, } \\
\text { the defect site } \\
\text { is covered with } \\
\text { matrix }\end{array}$ & $\begin{array}{l}\text { Taking } \\
\text { cylindrical } \\
\text { cartilage } \\
\text { plugs from a } \\
\text { donor site and } \\
\text { inserting them } \\
\text { into matching } \\
\text { holes }\end{array}$ & $\begin{array}{l}\text { Placing the } \\
\text { composite scaffolds } \\
\text { into the interface } \\
\text { between cartilage } \\
\text { and bone for } \\
\text { osteochondral defect } \\
\text { site repair }\end{array}$ & $\begin{array}{l}\text { Cartilage tissue is } \\
\text { taken from a non- } \\
\text { weight bearing area } \\
\text { for cell culture. } \\
\text { When cell number } \\
\text { is sufficient, the } \\
\text { chondrocytes are } \\
\text { applied on the } \\
\text { damaged area }\end{array}$ & $\begin{array}{l}\text { Cartilage tissue is } \\
\text { taken from a non- } \\
\text { weight bearing area for } \\
\text { cell culture. When cell } \\
\text { number is sufficient, } \\
\text { the chondrocytes are } \\
\text { seeded onto a scaffold } \\
\text { for damaged area repair }\end{array}$ \\
\hline Functions & Tissue repair & Tissue repair & Tissue repair & Tissue repair & Tissue repair & Tissue repair \\
\hline $\begin{array}{l}\text { Cell } \\
\text { cultivation }\end{array}$ & No & No & No & No & Yes & Yes \\
\hline Matrix & Without & With & Without & With & Without & With \\
\hline $\begin{array}{l}\text { Matrix } \\
\text { examples }\end{array}$ & - & $\begin{array}{l}\text { Chondro- } \\
\text { Gide }^{[079]} \text { BST- } \\
\text { CarGel }^{\text {[i } 80]}\end{array}$ & - & $\begin{array}{l}\text { PLGA/bioactive } \\
\text { glass }{ }^{[81]} \text {, cartilage } \\
\text { fragments combined } \\
\text { with PLGA/beta- } \\
\text { TCP composite }{ }^{[82]} \text {, } \\
\text { porous PLGA/nano- } \\
\text { hydroxyapatite hybrid } \\
\text { scaffolds }^{[83]}\end{array}$ & - & $\begin{array}{l}\text { Chondro-Gide }{ }^{[84]}, \\
\text { CaReS }^{\otimes[85]} \text {, Hyalograft } \\
C^{\oplus[86]} \text {, BioSeed-C }{ }^{\oplus[87]}, \\
\text { recycled cartilage } \\
\text { auto/allo implantation } \\
\text { (ClinicalTrials. } \\
\text { gov Identifier: } \\
\text { NCT03672825) }\end{array}$ \\
\hline
\end{tabular}

MF: micro-fracture; AMIC: matrix augmented micro fracture; OAT: osteochondral transplantation; ACI: autologous chondrocyte implantation; MACl: matrix-induced autologous chondrocyte implantation; PLGA: polylactide-co-glycolide; TCP: tricalcium phosphate

criteria established by International Society for Cellular Therapy including (1) being plastic-adherent in culture conditions; (2) expressing cluster of differentiation 105 (CD105), CD73, and CD90, lacking expression of $\mathrm{CD} 45, \mathrm{CD} 34, \mathrm{CD} 14$ or $\mathrm{CD} 11 \mathrm{~b}, \mathrm{CD} 79$ or $\mathrm{CD} 19$, and human leukocyte antigen-DR isotype (HLA-DR) surface molecules; and (3) possessing tri-lineage differentiation into osteoblasts, adipocytes and chondroblasts $^{[26]}$. Much of the recent literature has focused on BMSCs for chondrogenesis ${ }^{[27]}$. However, the clinical use of BMSCs has encountered challenges such as donor site morbidity, pain and low cell number upon harvest ${ }^{[28]}$. One issue is that only $0.001 \%-0.01 \%$ of the cells in bone marrow aspirate concentrate consist of BMSCs ${ }^{[22]}$. Thus, the ADSCs has become an attractive alternative source of MSCs because of its relatively easy accessibility and abundance during harvest ${ }^{[30]}$.

ADSCs can be isolated from the upper arm, medial thigh, buttocks, trochanteric, superficial deep abdominal depots, and even the infrapatellar fat pad (IPFP) within the knee joint. There are about 2 to 6 million cells in the stromal vascular fraction (SVF) which can be obtained in $1 \mathrm{~mL}$ lipoaspirate ${ }^{[31]}$. The number of ADSCs in $1 \mathrm{~g}$ of ADSCs may range from 5000 to $200,000^{[32-34]}$. In other words, if we isolated $100 \mathrm{~g}$ of ADSCs from patient, there would be 0.5 to 20 million ADSCs which can be extracted from the ADSCs. ADSCs have been reported to differentiate into adipocytes, osteoblasts ${ }^{[35]}$, chondrocytes ${ }^{[36]}$, and endothelial cells ${ }^{[37]}$ in view of their mesodermal origin. In addition, they have been described to have the ability to differentiate into ectodermal, and endodermal origin cells, such as vascular smooth muscle cells ${ }^{[38]}$, keratinocytes ${ }^{[39]}$, hepatocytes, beta islet cells ${ }^{[40]}$, neuron-like cells ${ }^{[41]}$ and glial lineages ${ }^{[42]}$. Both ADSCs and BMSCs exhibit a fibroblast-like morphology ${ }^{[35,43]}$, expressing CD29, CD44, CD73, CD90, CD105 while being absent for CD 14, CD31, CD 34, CD 45, CD106 and HLA-DR and c-kit expression ${ }^{[35,36,43]}$. When comparing the cell differentiation ability between ADSCs and BMSCs in vitro, ADSCs demonstrated more prominent adipogenic differentiation ability, while BMSCs possessed stronger osteogeneic differentiation ability compared to ADSCs ${ }^{[35,44]}$. Xu et al. ${ }^{[35]}$ used bisulfite PCR analysis to examine the DNA methylation status of Runx2, PPAR $\gamma$, and Sox9 from ADSCs and BMSCs. They described that the CpG sites of PPAR $\gamma$ promoter in BMSCs and the CpG sites of Runx2 promoter in ADSCs were hypermethylated. Nevertheless, the methylation status of Sox9 promoter in BMSCs was only slightly lower than that in ADSCs. 
In specific orthopaedic procedures such as high tibial osteotomy or arthroscopy examination, a part of patients' tissue are removed, such as the SDSCs and IPFP. A significant number of MSCs exit within the deposited tissue and can be isolated by collagenase digestion. Sakaguchi et al. ${ }^{[45]}$ compared the differentiation potential among BMSCs, SDSCs and ADSCs. They reported that the nucleated cell number of SDSCs was about 3000 per mg, and possessed the greatest chondrogenesis ability as compared with others. Moreover, they also found that proliferative potential of SDSCs and IPFP-MSC were greater than that of ADSC, and the pellets formed by SDSCs and IPFP-MSC could also produce more cartilage matrix than that in ADSCs pellets from another study ${ }^{[46]}$. Kouroupis et al. ${ }^{[4]}$ demonstrated that IPFP-MSC exhibit higher clonogenicity and chondrogenic potential as compared with BMSC. Importantly, their findings showed that primed IPFP-MSC demonstrate sustained antagonism of activated human peripheral blood mononuclear cells proliferation. Considering its chondrogenic and anti-inflammation ability, it appears that IPFP-MSC may be the most promising MSC type for degenerative/inflammatory joint diseases treatment.

\section{MSCs for OA treatment}

In early 2008, Centeno et al. ${ }^{[48]}$ published their inaugural research findings about the use of autologous BMSCs for OA treatment, where they cultured BMSCs to passage 3 and injected about $4.56 \times 10^{7}$ cells into a 36 years-old male's knee. After treatment for a 3-month period, the patient's VAS scores decreased from 3.33 to 0.13. Furthermore, his MRI results showed that the volume of meniscus increased. In 2011, Davatchi et al. ${ }^{[49]}$ published their results on the use of autologous BMSCs for OA treatment $(n=4)$, where they injected about 8 to $9 \times 10^{6}$ cells into patients' knee cavity. They reported that the walking time for the pain to appear improved and patient's VAS scores decreased from 80 90 to 45 65. However, they were unable to find any improvement on X-rays. This study was continued from follow-up to post-treatment 5 years, and they found that the beneficial effects of BMSCs started to decline after 6 months, although this was still better at 5 years compared to the baseline ${ }^{[50]}$. In 2013, Orozco et al. ${ }^{[51]}$ performed an OA clinical study $(n=12)$, in which they injected $4 \times 10^{7}$ BMSCs into Kellgren and Lawrence (KL) grade 2-4 patients' knee joints. They described that pain relief occurred by 3 months and improved for at least 1 year, and the Lequesne and WOMAC score were significantly increased. Moreover, the quantitative MRI results on cartilage quality showed improvement at the 2 -year follow-up ${ }^{[51]}$. Leading on, the same research team also published a BMSCs study in 2016, where they used $4 \times 10^{7}$ BMSCs to treat KL grade 2-3 OA treatment. Results showed that the daily activities VAS at the basal visit was about 58.27, and this value decreased to 19.47 at the 1-year a follow-up, with further reduction to $14.62 \pm 14.93$ at the 4-year follow-up, and no serious adverse effects were reported ${ }^{[52]}$. In 2019, Chahal et al. ${ }^{[53]}$ presented their research on using 1, 10, or 50 million BMSCs for KL grade 3-4 OA treatment. They found there were no improvements in morphological cartilage scores or decrease in T2 relaxation values. However, they showed possible chondroprotective effects based on cartilage catabolic biomarkers at 50 million BMSCs doses. They also found that IL12p40 within synovial fluid decreased with treatment, and the pro-inflammatory $\mathrm{CD} 14^{+} \mathrm{CD} 16^{+}$monocyte/macrophages maker tend to decrease as well after MSCs treatment.

Apart from bone marrow, ADSCs is another popular stem cell source. In Fodor's research, they treated OA knee with the use of 14.1 million viable, nucleated SVF cells, and found that there was a statistically significant improvement in WOMAC and VAS scores, which was maintained at 1 year $^{[54]}$. Prof. Yokota Nakamura also conducted a clinical study recently to compare OA treatment effect of ADSCs or noncultured SVF injection. Results showed that pain VAS and Knee injury and Osteoarthritis Outcome Score (KOOS) scores had improvement in both groups. Nonetheless, patients' symptoms improved earlier (at 3 months) and pain VAS decreased to a greater degree in the ADSCs injection group as compared with those in SVF group ${ }^{[55]}$. Adipose SVF contains a wide variety of cells including that of MSCs, pericytes, vascular adventitial cells, fibroblasts, pre-adipocytes, monocytes, macrophages, red blood cells, and fibrous tissue/matrix. The composition of these aforementioned cells or matrix may differ depending on individual differences or the preparation procedure of SVF. Thus, in some clinical studies evaluating the effects of 
MSCs, they are isolated and expanded in the laboratory, thereafter being injected into the OA knee for treatment.

In a study from Jo et al..$^{[9]}$, they present a 2-year follow-up result of IA injection of low $\left(1 \times 10^{7}\right)$, medium $\left(5 \times 10^{7}\right)$, and high $\left(1 \times 10^{8}\right)$ dose of ADSCs into the knee, respectively (NCT01300598). They report that MSCs improved knee function, as measured with the WOMAC, Knee Society clinical rating system, and KOOS, with patients experiencing reduced knee pain. In addition, there was a statistical significance of improvement found mainly in the high-dose group. However, in Pers's study (NCT01585857), they found the group of patients having injections of $2 \times 10^{6}$ cells exhibiting the best response, and they had higher baseline pain and WOMAC scores compared with those receiving higher doses ${ }^{[56]}$. In 2019, Lee et al. ${ }^{[57]}$ presented a prospective double-blinded, randomized controlled, phase IIb clinical trial, where they injected high-dose autologous ADSCs $\left(1 \times 10^{8}\right.$ cells $)$ intra-articularly into the patients' knee, and found that a single injection of ADSCs led to a significant improvement of the WOMAC score at 6 months. Furthermore, there was no significant change in cartilage defect at 6 months in ADSCs group which contrasted with the increased defect size in the control group. Lu et al. ${ }^{[58]}$ also conducted a double-blind, active-controlled, phase IIb knee OA clinical trial by using $5 \times 10^{7}$ ADSCs. Results showed that most patients achieved a 70\% improvement rate in the ADSCs receiving group after 12 months. Moreover, there was a notable increase in articular cartilage volume in the ADSC group, as compared with the hyaluronic acid (HA) group after 12 months as measured by MRI.

Recently, another type of fat tissue known as PFP has become a popular research topic due to its ability to diminish inflammation and cartilage degenerative grade. The IPFP is an intra-capsular structure within the anterior knee compartment, composed of approximately $20 \mathrm{~cm}^{3}$ of $\mathrm{ADSCs}^{[59]}$, and may be easily harvested arthroscopically or during open knee surgery ${ }^{[60]}$. During embryonic development of the knee, researchers found that IPFP initiates from interzone formation between the femur and tibia, progressing to cavitation between this region, and finally a IPFP site formation. This is described to be a triangular space composed of a mesenchymal tissue formation below the patella at the 9 th week of human development ${ }^{[61]}$. IPFP occupies space in the joint, maintaining the articular cavity, allowing the synovial fluid to circulate over the joint thus contributing to lubrication. In an experimental animal model of OA, Toghraie et al. ${ }^{[62]}$ used direct IA injection of IPFP-MSCs into the OA knees of rabbits. The IPFP-MSCs used had been expanded and grown in vitro and were delivered 12 weeks after the operation in a single dose of 1 million cells suspended in $1 \mathrm{~mL}$ of medium. Twenty weeks after surgery, rabbits that received IF-MSCs demonstrated less cartilage degeneration, osteophyte formation, and subchondral sclerosis than did those in the control group.

In 2012, Koh published a Level III clinical study article with the use of IPFP-MSCs for OA therapy ${ }^{[60]}$, where they collected the IPFP (average weight, 9.4 g; range, 6.9-11.2 g) by skin incision extension, further isolating the IPFP-MSCs by tissue mincing, collagen digestion, and centrifugation. An average of $1.89 \times 10^{6}$ stem cells were prepared with $3.0 \mathrm{~mL}$ of PRP and injected into the selected knees of patients in the study group. The mean Lysholm and VAS scores of patients in the study group improved significantly at the final follow-up (mean follow-up, 24.3 months; range, 24 to 26 months). Radiography demonstrated that the whole-organ MRI score had significantly improved from 60.0 points to 48.3 points ${ }^{[63]}$. Spasovski et al. ${ }^{[64]}$ have also reported that the use of IPFP-MSCs in knee OA improves clinical symptoms and reduces pain at 3 months, obtaining the best results at 6 months. Currently, a phase 1 clinical study entitled "Treatment of Knee Osteoarthritis with Autologous Mesenchymal Stromal Cell Product (RegStem ${ }^{\circ}$ )" is being conducted in Taiwan, which has been approved by Taiwan Food and Drug Administration on May, 2017 (ClinicalTrials. gov Identifier number: NCT03007576). The study has enrolled 12 subjects who have Kellgren-Lawrence grade $2 \sim 3$ OA knee, and use $5 \times 10^{7}$ IPFP-MSCs for therapy. At the culmination of 1, 3, 6, 12 and 24 months, the VAS, KOOS and IKDC scores of subjects will be further evaluated. 


\section{MSCs for cartilage defect treatment}

Even though the clinical outcome of MF, OAT and ACI for cartilage defect treatment has been shown to be desirable, there are some limitations, including that of low stem cell number and fibrocartilage formation in MF treatment, potential donor-site morbidity in OAT technique, and requirements for secondary surgery in ACI procedure. Thus, there are several research teams trying to isolate and proliferate the stem cell from patient's autologous tissue, re-seeding them into the tissue for cartilage defect treatment. They anticipate that high proliferation rate and chondro-differentiation potential of stem cells could potentially regenerate the cartilage tissue.

In 2002, Wakitani et al. ${ }^{[65]}$ first presented using BMSCs for cartilage defect treatment, where they mixed $1.3 \times 10^{7}$ cells into $2 \mathrm{~mL}$ of $0.25 \%$ type I collagen gel and placed the gel-cell composite onto the defect site. One year later, they discovered that the defects sites were covered with white soft hyaline cartilagelike tissue, and reported metachromasia within the cartilage tissue where there was presence of hyaline cartilage-like tissue forming. Recently, Nejadnik et al. ${ }^{[6]}$ also compared the clinical results of cartilage defect repaired by 10-15 million chondrocytes or BMSCs. They found improvement in the quality of life of both patient groups, and there was no significant difference in IKDC, Lysholm, and Tegner scores. However, the use of BMSCs for cartilage defect treatment is a one stage surgery, and this modality of treatment may reduce costs, further minimizing the probability of donor-site morbidity. In another related research conducted by Haleem et al ${ }^{[67]}$, they combined BMSCs and PRP for cartilage defect treatment, and the BMSCs seeding density was $\sim 2 \times 10^{6}$ cells $/ \mathrm{cm}^{2}$. They found after cell injection the Lysholm and RHSSK scores showed statistically significant improvement at 12 -month follow-up, and MRI revealed complete defect filled with native cartilage. Considering long-term treatment outcome, Teo et al. ${ }^{[68]}$ published his 10-year follow-up clinical research comparing patient-reported outcome between BMSCs and chondrocyte for cartilage repair. They found no significant differences between these two groups, and also no apparent increased tumor formation risk. However, cell isolation and cultivation are easier when using BMSCs for cartilage repair. Synovial MSCs are an alternative stem cell source for cartilage defect repair, where these cells have been extensively studied by Prof. Ichiro Sekiya. Research indicates that the SDSCs is a reservoir for MSCs which can contribute to intraarticular tissue repair ${ }^{[69]}$. In 2015, Sikiya's team conducted a synovial MSCs for cartilage defect treatment clinical study, where they isolated synovial MSCs and cultured them for 14 days, thereafter placing them on the cartilage defect site. Results showed that Lysholm scores were improved, and MRI score was increased at 18-months follow-up ${ }^{[70]}$. In 2015, Prof. Norimasa Nakamura developed a new method for cartilage repair, known as a scaffold-free tissue engineered construct (TEC). The construct was made by synovium-derived stem cells (SDSCs), where the team cultured cells in a medium with $>0.1 \mathrm{mmol} / \mathrm{L}$ ascorbic acid-2 phosphate for a period, resulting in a stiff sheet-like TEC which was rich in collagen I and III ${ }^{[71]}$.

In Taiwan, there are several research teams which have tried to use MSCs for cartilage regeneration. Researchers developed an MSCs-derived chondrocyte implantation technique in 2005, and the technique obtained a US patent (patent number: US 20110189254 A1) entitled "Surgical grafts for repairing chondral defects". In this technique, BMSCs were isolated from patients' bone marrow and embedded in 3\% type-I collagen solution in a $2.6 \times 10^{6} \mathrm{cells} / \mathrm{cm}^{2}$ cell density for cartilage repair. The gel/cell composite could gel in 12-well plates for an hour, and this was then overlaid with $2 \mathrm{~mL}$ chondrogenic differentiation medium for cartilage-like tissue induction. About 3 weeks later, the gel/cell composite reseeded into the cartilage defect site. This clinical study enrolled 12 human subjects and continued to follow up their clinical outcome and MRI results for about 9 years, results confirming that there were an improvement in IKDC and MRI score.

In 2011, Chang et al. ${ }^{[72]}$ studied the possibility of using BMSCs containing tissue-engineering constructs for osteochondral defects repair in a porcine model. They used the gel/cell composite with a $1 \times 10^{6} \mathrm{BMSCs} / \mathrm{mL}$ cell density for cartilage regeneration. They found that both undifferentiated MSCs and TGF- $\beta$-induced 
differentiated MSCs could be used for in vivo tissue engineering treatment of osteochondral defects. Six months after surgery, they discovered that the defects had smooth, fully repaired surfaces or partially repaired surfaces in both group, suggesting that the use of MSCs could be a viable approach for in vivo tissue engineered treatment of osteochondral defects.

Based on the concept that ECM may possess critical factors for MSC differentiation, some research groups have focused on combining cartilage matrix and MSC for cartilage repair. In 2012, Chen et al. ${ }^{[73]}$ mixed $6 \times 10^{6}$ BMSCs with cartilage fragment as a construct for cartilage regeneration and implanted it subcutaneously into nude mice. Results showed that the cells cultured in the constructs expressed type II collagen mRNA after 4 weeks of implantation. This implied that the cartilage fragments could promote chondrogenic differentiation of BMSCs. In a following study, they prepared the acellular cartilage matrix (ACM) from patients' cartilage tissue and mixed it with human SDSCs and collagen gel for in vitro culture. Results showed that SMSCs also express type II collagen and SOX-9 mRNA in an environment with growth factor absence. Thus such kind of ACM/stem cell composites may be beneficial to cartilage regeneration for future clinical applications ${ }^{[74]}$. In 2017, the group tried to compare the cartilage regeneration results between BMSCs and bone marrow concentrate (BMC). They mixed porcine cartilage, SDSCs fragments with BMSCs or BMC to form different constructs. Results showed that BMC-containing constructs could stimulate chondrogenesis and BMSCs-containing constructs could assist in ECM synthesis ${ }^{[75]}$.

\section{Challenges in using MSCs for cartilage regeneration}

For cartilage regeneration, MSCs may be applied to knee joint injection or cartilage defect filling, but obtaining a high cell number remains a challenge. Patients are unable to receive their own high cell number MSCs immediately. Their MSC contained tissue would be sent to the qualified cell processing facility for cell isolation and expansion, and the expected cell receiving date might be up to three weeks later ${ }^{[57]}$. After MSCs are injected into knee joint, it is uncertain if the MSCs are well-dsistributed. Furthermore, in order to meet the high cell number, the MSCs are cultured in vitro for a long duration, where their phonotype may be changed, the cell population's doubling time would increase and cellular aging process occurs ${ }^{[76]}$.

\section{CONCLUSION}

There are several biological factors related to OA and cartilage defect, which eventually lead to cartilage degeneration. The most common clinical treatment for cartilage degeneration involves the use of painkillers and HA injection. However, such kind of treatment may only serve to reduce the symptoms, and not to repair or regenerate the cartilage. Thus, several operative treatments were developed for cartilage repair, including MF, OAT and ACI. These operative surgeries are common in orthopedic surgery, but there is still room for advancement. Currently, several research groups have focused on the use of MSCs for cartilage repair, and most involve bone marrow and ADSCs as sources of MSCs. The majority of these have shown promising results in cartilage repair and OA treatment. Infrapatellar fat pads MSCs is a recent hot research topic as it possesses promising potential for OA and cartilage defect treatment.

\section{DECLARATIONS}

\section{Acknowledgments}

The authors would like to thank Ministry of Science and Technology (108-2314-B-418-010-MY3) and Far Eastern Memorial Hospital (FEMH -2019-C-004, FEMH-2019-C-080, FEMH-2017-C-007, FEMH2017-C-046) for financial support and the Far Eastern Memorial Hospital Core Laboratories I \& II for providing facilities and instruments.

\section{Authors' contributions}

Made substantial contributions to conception and design of the study and performed data analysis and interpretation: Chen YC, Chang $\mathrm{CH}$ 
Performed data acquisition, as well as provided administrative, technical, and material support: Chen YC, Chang $\mathrm{CH}$

\section{Availability of data and materials}

Not applicable.

\section{Financial support and sponsorship}

This work was supported by Ministry of Science and Technology (MOST-108-2314-B-418-010-MY3, MOST 109-2314-B-418-002-MY3) and Far Eastern Memorial Hospital (FEMH -2019-C-004, FEMH2019-C-080, FEMH-2017-C-007, FEMH-2017-C-046).

\section{Conflicts of interest}

All authors declared that there are no conflicts of interest.

\section{Ethical approval and consent to participate}

Not applicable.

\section{Consent for publication}

Not applicable.

\section{Copyright}

c) The Author(s) 2020.

\section{REFERENCES}

1. Aigner T, Stove J. Collagens--major component of the physiological cartilage matrix, major target of cartilage degeneration, major tool in cartilage repair. Adv Drug Deliv Rev 2003;55:1569-93.

2. Mow VC, Setton LA. Mechanical properties of normal and osteoarthritic articular cartilage. In: Brandt KD, Doherty M, Lohmander LS, editors. Osteoarthritis. Oxford: Oxford University Press; 1998. pp. 108-22.

3. Mauck LR, Burdick JA. Engineering cartilage tissue. In: Pallua N, Suschek CV, editors. Tissue Engineering, from lab to clinic. UK: Springer-Verlag Berlin Heidelberg; 2011. pp. 493-520.

4. Bastiaansen-Jenniskens YM, Koevoet W, de Bart AC, van der Linden JC, Zuurmond AM, et al. Contribution of collagen network features to functional properties of engineered cartilage. Osteoarthritis Cartilage 2008;16:359-66.

5. Arden N, Nevitt MC. Osteoarthritis: epidemiology. Best Pract Res Clin Rheumatol 2006;20:3-25.

6. Kotlarz H, Gunnarsson CL, Fang H, Rizzo JA. Insurer and out-of-pocket costs of osteoarthritis in the US: evidence from national survey data. Arthritis Rheum 2009;60:3546-53.

7. Fransen M, Bridgett L, March L, Hoy D, Penserga E, et al. The epidemiology of osteoarthritis in Asia. Int J Rheum Dis 2011;14:113-21.

8. Neogi T, Zhang Y. Epidemiology of osteoarthritis. Rheum Dis Clin North Am 2013;39:1-19.

9. Jo CH, Chai JW, Jeong EC, Oh S, Shin JS, et al. Intra-articular injection of mesenchymal stem cells for the treatment of osteoarthritis of the Knee: a 2-year follow-up study. Am J Sports Med 2017;45:2774-83.

10. Saklatvala J. Tumour necrosis factor alpha stimulates resorption and inhibits synthesis of proteoglycan in cartilage. Nature 1986;322:547-9.

11. Lefebvre V, Peeters-Joris C, Vaes G. Modulation by interleukin 1 and tumor necrosis factor alpha of production of collagenase, tissue inhibitor of metalloproteinases and collagen types in differentiated and dedifferentiated articular chondrocytes. Biochim Biophys Acta 1990;22:366-78.

12. Kaneko S, Satoh T, Chiba J, Ju C, Inoue K, et al. Interleukin-6 and interleukin-8 levels in serum and synovial fluid of patients with osteoarthritis. Cytokines Cell Mol Ther 2000;6:71-9.

13. Sokolove J, Lepus CM. Role of inflammation in the pathogenesis of osteoarthritis: latest findings and interpretations. Ther Adv Musculoskelet Dis 2013;5:77-94.

14. Kapoor M, Martel-Pelletier J, Lajeunesse D, Pelletier JP, Fahmi H. Role of proinflammatory cytokines in the pathophysiology of osteoarthritis. Nat Rev Rheumatol 2011;7:33-42.

15. Harris DJ, Flanigan DC. Management of knee articular cartilage injuries. In: Dragoo JL, editor. Modern Arthroscopy. InTech; 2011. pp. 103-28.

16. Bhatia D, Bejarano T, Novo M. Current interventions in the management of knee osteoarthritis. J Pharm Bioallied Sci 2013;5:30-8.

17. Jones IA, Togashi R, Wilson ML, Heckmann N, Vangsness CT Jr. Intra-articular treatment options for knee osteoarthritis. Nat Rev Rheumatol 2019;15:77-90. 
18. Rabago D, Patterson JJ, Mundt M, Kijowski R, Grettie J, et al. Dextrose prolotherapy for knee osteoarthritis: a randomized controlled trial. Ann Fam Med 2013;11:229-37.

19. Glynn LG, Mustafa A, Casey M, Krawczyk J, Blom J, et al. Platelet-rich plasma (PRP) therapy for knee arthritis: a feasibility study in primary care. Pilot Feasibility Stud 2018;4:93.

20. Mancuso P, Raman S, Glynn A, Barry F, Murphy JM. Mesenchymal stem cell therapy for osteoarthritis: the critical role of the cell secretome. Front Bioeng Biotechnol 2019;7:9.

21. Case JM, Scopp JM. Treatment of articular cartilage defects of the knee with microfracture and enhanced microfracture techniques. Sports Med Arthrosc Rev 2016;24:63-8.

22. Inderhaug E, Solheim E. Osteochondral autograft transplant (mosaicplasty) for knee articular cartilage defects. JBJS Essent Surg Tech 2019;9:e34.1-2.

23. Kim MK, Park JS, Jeon YM, Jeon YS. Clinical, radiological, and histological outcomes after the fibrin-matrix autologous chondrocyte implantation for chondral lesions of the knee in patients more than 50 years old: a prospective case series with minimum 2-year followup. J Orthop Surg (Hong Kong) 2020;28:2309499019893509.

24. Erickson BJ, Strickland SM, Gomoll AH. Indications, techniques, outcomes for matrix-induced autologous chondrocyte implantation (MACI). Oper Tech Sports Med 2018;26:175-82.

25. Pers YM, Ruiz M, Noel D, Jorgensen C. Mesenchymal stem cells for the management of inflammation in osteoarthritis: state of the art and perspectives. Osteoarthritis Cartilage 2015;23:2027-35.

26. Dominici M, Le Blanc K, Mueller I, Slaper-Cortenbach I, Marini F, et al. Minimal criteria for defining multipotent mesenchymal stromal cells. The international society for cellular therapy position statement. Cytotherapy 2006;8:315-7.

27. Gupta PK, Das AK, Chullikana A, Majumdar AS. Mesenchymal stem cells for cartilage repair in osteoarthritis. Stem Cell Res Ther 2012;3:25.

28. Chen YC, Chen CH, Chen PL, Huang IY, Shen YS, et al. Donor site morbidity after harvesting of proximal tibia bone. Head Neck 2006;28:496-500.

29. Cotter EJ, Wang KC, Yanke AB, Chubinskaya S. Bone marrow aspirate concentrate for cartilage defects of the knee: from bench to bedside evidence. Cartilage 2018;9:161-70.

30. Nathan S, Das De S, Thambyah A, Fen C, Goh J, et al. Cell-based therapy in the repair of osteochondral defects: a novel use for adipose tissue. Tissue Eng 2003;9:733-44.

31. Si Z, Wang X, Sun C, Kang Y, Xu J, et al. Adipose-derived stem cells: Sources, potency, and implications for regenerative therapies. Biomed Pharmacother 2019;114:108765.

32. Baer PC, Geiger H. Adipose-derived mesenchymal stromal/stem cells: tissue localization, characterization, and heterogeneity. Stem Cells Int 2012;2012:812693.

33. Pak J, Lee JH, Park KS, Park M, Kang LW, et al. Current use of autologous adipose tissue-derived stromal vascular fraction cells for orthopedic applications. J Biomed Sci 2017;24:9.

34. De Ugarte DA, Morizono K, Elbarbary A, Alfonso Z, Zuk PA, et al. Comparison of multi-lineage cells from human adipose tissue and bone marrow. Cells Tissues Organs 2003;174:101-9.

35. Xu L, Liu Y, Sun Y, Wang B, Xiong Y, et al. Tissue source determines the differentiation potentials of mesenchymal stem cells: a comparative study of human mesenchymal stem cells from bone marrow and adipose tissue. Stem Cell Res Ther 2017;8:275.

36. Heo JS, Choi Y, Kim HS, Kim HO. Comparison of molecular profiles of human mesenchymal stem cells derived from bone marrow, umbilical cord blood, placenta and adipose tissue. Int J Mol Med 2016;37:115-25.

37. Deng M, Gu Y, Liu Z, Qi Y, Ma GE, et al. Endothelial differentiation of human adipose-derived stem cells on polyglycolic acid/polylactic acid mesh. Stem Cells Int 2015;2015:350718.

38. Lin J, Zhu Q, Huang J, Cai R, Kuang Y. Hypoxia promotes vascular smooth muscle cell (VSMC) differentiation of adipose-derived stem cell (ADSC) by regulating mett13 and paracrine factors. Stem Cells Int 2020;2020:2830565.

39. Edwards NJ, Stone R, Christy R, Zhang CK, Pollok B, et al. Differentiation of adipose derived stem cells to keratinocyte-like cells on an advanced collagen wound matrix. Tissue Cell 2018;53:68-75.

40. Wada Y, Ikemoto T, Morine Y, Imura S, Saito Y, et al. The differences in the characteristics of insulin-producing cells using human adipose-tissue derived mesenchymal stem cells from subcutaneous and visceral tissues. Sci Rep 2019;9:13204.

41. Gao S, Guo X, Zhao S, Jin Y, Zhou F, et al. Differentiation of human adipose-derived stem cells into neuron/motoneuron-like cells for cell replacement therapy of spinal cord injury. Cell Death Dis 2019;10:597.

42. Tomita K, Madura T, Sakai Y, Yano K, Terenghi G, et al. Glial differentiation of human adipose-derived stem cells: implications for cellbased transplantation therapy. Neuroscience 2013;236:55-65.

43. Lee RH, Kim B, Choi I, Kim H, Choi HS, et al. Characterization and expression analysis of mesenchymal stem cells from human bone marrow and adipose tissue. Cell Physiol Biochem 2004;14:311-24.

44. Tsuji W, Rubin JP, Marra KG. Adipose-derived stem cells: implications in tissue regeneration. World J Stem Cells 2014;6:312-21.

45. Sakaguchi Y, Sekiya I, Yagishita K, Muneta T. Comparison of human stem cells derived from various mesenchymal tissues - Superiority of synovium as a cell source. Arthritis Rheum 2005;52:2521-9.

46. Mochizuki T, Muneta T, Sakaguchi Y, Nimura A, Yokoyama A, et al. Higher chondrogenic potential of fibrous synovium- and adipose synovium-derived cells compared with subcutaneous fat-derived cells: distinguishing properties of mesenchymal stem cells in humans. Arthritis Rheum 2006;54:843-53.

47. Kouroupis D, Bowles AC, Willman MA, Perucca Orfei C, Colombini A, et al. Infrapatellar fat pad-derived MSC response to inflammation 
and fibrosis induces an immunomodulatory phenotype involving CD10-mediated Substance P degradation. Sci Rep 2019;9:10864.

48. Centeno CJ, Busse D, Kisiday J, Keohan C, Freeman M, et al. Regeneration of meniscus cartilage in a knee treated with percutaneously implanted autologous mesenchymal stem cells. Med Hypotheses 2008;71:900-8.

49. Davatchi F, Abdollahi BS, Mohyeddin M, Shahram F, Nikbin B. Mesenchymal stem cell therapy for knee osteoarthritis. Preliminary report of four patients. Int J Rheum Dis 2011;14:211-5.

50. Davatchi F, Abdollahi BS, Mohyeddin M, Nikbin B. Mesenchymal stem cell therapy for knee osteoarthritis: 5 years follow-up of three patients. Int J Rheum Dis 2016;19:219-25.

51. Orozco L, Munar A, Soler R, Alberca M, Soler F, et al. Treatment of knee osteoarthritis with autologous mesenchymal stem cells: twoyear follow-up results. Transplantation 2014;97:e66-8.

52. Soler R, Orozco L, Munar A, Huguet M, Lopez R, et al. Final results of a phase I-II trial using ex vivo expanded autologous mesenchymal stromal cells for the treatment of osteoarthritis of the knee confirming safety and suggesting cartilage regeneration. Knee 2016;23:647-54.

53. Chahal J, Gómez-Aristizábal A, Shestopaloff K, Bhatt S, Chaboureau A, et al. Bone marrow mesenchymal stromal cell treatment in patients with osteoarthritis results in overall improvement in pain and symptoms and reduces synovial inflammation. Stem Cells Transl Med 2019;8:746-57.

54. Fodor PB, Paulseth SG. Adipose derived stromal cell (ADSC) injections for pain management of osteoarthritis in the human knee joint. Aesthet Surg J 2016;36:229-36.

55. Yokota N, Hattori M, Ohtsuru T, Otsuji M, Lyman S, et al. Comparative clinical outcomes after intra-articular injection with adiposederived cultured stem cells or noncultured stromal vascular fraction for the treatment of knee osteoarthritis. Am J Sports Med 2019;47:2577-83.

56. Pers YM, Rackwitz L, Ferreira R, Pullig O, Delfour C, et al. ADIPOA Consortium. Adipose mesenchymal stromal cell-based therapy for severe osteoarthritis of theknee: a phase I dose-escalation trial. Stem Cells Transl Med 2016;5:847-56.

57. Lee WS, Kim HJ, Kim KI, Kim GB, Jin W. Intra-articular injection of autologous adipose tissue-derived mesenchymal stem cells for the treatment of knee osteoarthritis: a phase IIb, randomized, placebo-controlled clinical trial. Stem Cells Transl Med 2019;8:504-11.

58. Lu L, Dai C, Zhang Z, Du H, Li S, et al. Treatment of knee osteoarthritis with intra-articular injection of autologous adipose-derived mesenchymal progenitor cells: a prospective, randomized, double-blind, active-controlled, phase IIb clinical trial. Stem Cell Res Ther 2019;10:143.

59. Chuckpaiwong B, Charles HC, Kraus VB, Guilak F, Nunley JA. Age-associated increases in the size of the infrapatellar fat pad in knee osteoarthritis as measured by 3T MRI. J Orthop Res 2010;28:1149-54.

60. Koh YG, Choi YJ. Infrapatellar fat pad-derived mesenchymal stem cell therapy for knee osteoarthritis. Knee 2012;19:902-7.

61. do Amaral R, Almeida HV, Kelly DJ, O’Brien FJ, Kearney CJ. Infrapatellar fat pad stem cells: from developmental biology to cell therapy. Stem Cells Int 2017;2017:6843727.

62. Toghraie FS, Chenari N, Gholipour MA, Faghih Z, Torabinejad S, et al. Treatment of osteoarthritis with infrapatellar fat pad derived mesenchymal stem cells in Rabbit. Knee 2011;18:71-5.

63. Koh YG, Jo SB, Kwon OR, Suh DS, Lee SW, et al. Mesenchymal stem cell injections improve symptoms of knee osteoarthritis. Arthroscopy 2013;29:748-55.

64. Spasovski D, Spasovski V, Bascarevic Z, Stojiljkovic M, Vreca M, et al. Intra-articular injection of autologous adipose-derived mesenchymal stem cells in the treatment of knee osteoarthritis. J Gene Med 2018;20:e3002.

65. Wakitani S, Imoto K, Yamamoto T, Saito M, Murata N, et al. Human autologous culture expanded bone marrow mesenchymal cell transplantation for repair of cartilage defects in osteoarthritic knees. Osteoarthritis Cartilage 2002;10:199-206.

66. Nejadnik H, Hui JH, Feng Choong EP, Tai BC, Lee EH. Autologous bone marrow-derived mesenchymal stem cells versus autologous chondrocyte implantation: an observational cohort study. Am J Sports Med 2010;38:1110-6.

67. Haleem AM, Singergy AAE, Sabry D, Atta HM, Rashed LA, et al. The clinical use of human culture-expanded autologous bone marrow mesenchymal stem cells transplanted on platelet-rich fibrin glue in the treatment of articular cartilage defects: a pilot study and preliminary results. Cartilage 2010;1:253-61.

68. Teo AQA, Wong KL, Shen L, Lim JY, Toh WS, et al. Equivalent 10-year outcomes after implantation of autologous bone marrow-derived mesenchymal stem cells versus autologous chondrocyte implantation for chondral defects of the knee. Am J Sports Med 2019;47:2881-7.

69. Koga H, Shimaya M, Muneta T, Nimura A, Morito T, et al. Local adherent technique for transplanting mesenchymal stem cells as a potential treatment of cartilage defect. Arthritis Res Ther 2008;10:R84.

70. Sekiya I, Muneta T, Horie M, Koga H. Arthroscopic transplantation of synovial stem cells improves clinical outcomes in knees with cartilage defects. Clin Orthop Relat Res 2015;473:2316-26.

71. Shimomura K, Ando W, Moriguchi Y, Sugita N, Yasui Y, et al. Next generation mesenchymal stem cell (MSC)-based cartilage repair using scaffold-free tissue engineered constructs generated with synovial mesenchymal stem cells. Cartilage 2015;6:13S-29S

72. Chang CH, Kuo TF, Lin FH, Wang JH, Hsu YM, et al. Tissue engineering-based cartilage repair with mesenchymal stem cells in a porcine model. J Orthop Res 2011;29:1874-80.

73. Chen CC, Liao CH, Wang YH, Hsu YM, Huang SH, et al. Cartilage fragments from osteoarthritic knee promote chondrogenesis of mesenchymal stem cells without exogenous growth factor induction. J Orthop Res 2012;30:393-400.

74. Chang $\mathrm{CH}$, Chen $\mathrm{CC}$, Liao CH, Lin FH, Hsu YM, et al. Human acellular cartilage matrix powders as a biological scaffold for cartilage tissue engineering with synovium-derived mesenchymal stem cells. J Biomed Mater Res A 2014;102:2248-57.

75. Chen CC, Hsiao CY, Wang YH, Chen YC, Chang CH, et al. A comparison of distinct bone marrow-derived cells on cartilage tissue engineering. J Taiwan Inst Chem Eng 2017;78:32-8. 
76. Yang YK, Ogando CR, Wang See C, Chang TY, Barabino GA. Changes in phenotype and differentiation potential of human mesenchymal stem cells aging in vitro. Stem Cell Res Ther 2018;9:131.

77. Raynauld JP, Buckland-Wright C, Ward R, Choquette D, Haraoui B, et al. Safety and efficacy of long-term intraarticular steroid injections in osteoarthritis of the knee: a randomized, double-blind, placebo-controlled trial. Arthritis Rheum 2003;48:370-7.

78. Ray TR. Using viscosupplementation to treat knee osteoarthritis. Phys Sportsmed 2013;41:16-24.

79. Volz M, Schaumburger J, Frick H, Grifka J, Anders S. A randomized controlled trial demonstrating sustained benefit of Autologous Matrix-Induced Chondrogenesis over microfracture at five years. Int Orthop 2017;41:797-804.

80. Shive MS, Stanish WD, McCormack R, Forriol F, Mohtadi N, et al. BST-CarGel $®$ treatment maintains cartilage repair superiority over microfracture at 5 years in a multicenter randomized controlled trial. Cartilage 2015;6:62-72.

81. Jiang J, Tang A, Ateshian GA, Guo XE, Hung CT, et al. Bioactive stratified polymer ceramic-hydrogel scaffold for integrative osteochondral repair. Ann Biomed Eng 2010;38:2183-96.

82. Chiang H, Liao CJ, Hsieh CH, Shen CY, Huang YY, et al. Clinical feasibility of a novel biphasic osteochondral composite for matrixassociated autologous chondrocyte implantation. Osteoarthritis Cartilage 2013;21:589-98.

83. Xue D, Zheng Q, Zong C, Li Q, Li H, et al. Osteochondral repair using porous poly(lactide-co-glycolide)/nano-hydroxyapatite hybrid scaffolds with undifferentiated mesenchymal stem cells in a rat model. J Biomed Mater Res A 2010;94:259-70.

84. McCarthy HS, Roberts S. A histological comparison of the repair tissue formed when using either Chondrogide ${ }^{\circ}$ or periosteum during autologous chondrocyte implantation. Osteoarthritis Cartilage 2013;21:2048-57.

85. Schneider U, Rackwitz L, Andereya S, Siebenlist S, Fensky F, et al. A prospective multicenter study on the outcome of type I collagen hydrogel-based autologous chondrocyte implantation (CaReS) for the repair of articular cartilage defects in the knee. Am J Sports Med 2011;39:2558-65.

86. Trattnig S, Pinker K, Krestan C, Plank C, Millington S, et al. Matrix-based autologous chondrocyte implantation for cartilage repair with Hyalograft ${ }^{\circledR}$ C: two-year follow-up by magnetic resonance imaging. Eur J Radiol 2006;57:9-15.

87. Erggelet C, Kreuz PC, Mrosek EH, Schagemann JC, Lahm A, et al. Autologous chondrocyte implantation versus ACI using 3D-bioresorbable graft for the treatment of large full-thickness cartilage lesions of the knee. Arch Orthop Trauma Surg 2010;130:957-64. 